\title{
Belgeo
}

Revue belge de géographie

1 | 2009

Recent developments in economic geography Miscellaneous

\section{Why land use patterns affect travel behaviour (or not)}

Toward a "state-of-the-art" conceptual framework and an appropriate modelling technique

Waarom (of waarom niet) verplaatsingsgedrag beïnvloed wordt door

ruimtegebruik. Naar een "state-of-the-art" conceptueel kader en een geschikte

modelleertechniek

\section{Veronique Van Acker and Frank Witlox}

\section{(2) OpenEdition}

\section{Journals}

Electronic version

URL: http://journals.openedition.org/belgeo/8777

DOI: $10.4000 /$ belgeo.8777

ISSN: 2294-9135

\section{Publisher:}

National Committee of Geography of Belgium, Société Royale Belge de Géographie

Printed version

Date of publication: 31 March 2009

Number of pages: 5-26

ISSN: 1377-2368

\section{Electronic reference}

Veronique Van Acker and Frank Witlox, "Why land use patterns affect travel behaviour (or not) ", Belgeo [Online], 1 | 2009, Online since 19 May 2013, connection on 25 June 2020. URL : http:// journals.openedition.org/belgeo/8777; DOI : https://doi.org/10.4000/belgeo.8777

This text was automatically generated on 25 June 2020 .

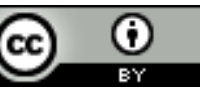

Belgeo est mis à disposition selon les termes de la licence Creative Commons Attribution 4.0 International. 


\section{Why land use patterns affect travel behaviour (or not)}

Toward a "state-of-the-art" conceptual framework and an appropriate modelling technique

Waarom (of waarom niet) verplaatsingsgedrag beïnvloed wordt door

ruimtegebruik. Naar een "state-of-the-art" conceptueel kader en een geschikte

modelleertechniek

Veronique Van Acker and Frank Witlox

1 Like in most countries, the overall amount of travel in Belgium has increased substantially. Within 10 years time, total travel distance has increased by more than a quarter: from 70 billion vehicle-kms in 1990 to 90 billion vehicle-kms in 2000 (http:// www.mobilit.fgov.be/). Because travel is associated with negative externalities such as congestion and pollution, policymakers try to control and manage travel patterns. Illustrative are the New Urbanism movement in the United States and the Compact City Policy in Europe, that aim at reducing car use and travel distances through urban planning. The basic idea is that high-density and mixed-use neighbourhoods are believed to be associated with shorter trips and more non-motorized trips; hence, indicating a clear existing relationship between land use and travel behaviour. Although numerous studies exist that try to measure and explain the strength of this relationship (for a review, see, e.g. van Wee, 2002; Ewing and Cervero, 2001), there is little consensus to be found in the conclusions of these studies. Some studies (e.g., Meurs and Haaijer, 2001) indicate that various land use characteristics are linked with travel behaviour, while others (e.g., Schwanen, 2002) state the opposite.

In our view these inconsistent conclusions result from the fact that certain variables are not fully taken into account. The models are usually controlled for socio-economic differences among respondents. Still, within "homogeneous groups" (i.e., respondents that are to be considered more or less identical in socio-economic terms) there may be socio-psychological traits, such as lifestyles and attitudes, which also have an impact on travel behaviour. Far less is known about the conceptual relationship that exists 
between travel behaviour and spatial, socio-economic, and socio-psychological constructs. Answering this query would involve combining and linking theories stemming from transport geography and social psychology.

Inconsistent conclusions also occur because of interdependencies that are not fully taken into account in the modelling approach. For example, indirect effects caused by relationships among the explanatory variables of travel behaviour are generally neglected. Moreover, several travel behaviour aspects are related to each other (for example, modal choice is associated with travel distance and time), resulting in indirect effects as well. Another example relates to interdependencies that exist between several levels of data aggregation. This problem refers to a data structure of individuals nested within households, households nested within neighbourhoods, etc. Because of this nested data structure, the individual's characteristics depend on the household's characteristics, the household's characteristics are related to the neighbourhood characteristics, and so on.

4 The present paper aims to contribute to the literature on travel behaviour conceptualization and modelling by taking a closer look at the two above-mentioned interdependencies. The paper is structured as follows. In Sections 2 and 3 the relationship between spatial, socio-economic and socio-psychological characteristics and travel behaviour is explored. We reveal the key variables in empirical studies on the relationship between land use and daily travel behaviour through an extensive literature review (Section 2). Section 3 analyzes several theoretical frameworks, resulting in a comprehensive conceptual model of travel behaviour. This is an important contribution of this paper. In Section 4 an appropriate methodological framework is advanced that concurs with our conceptual model. This section includes a theoretical discussion on how travel behaviour can be analyzed using multilevel structural equation models. Finally, in the last section, some conclusions are drawn.

\section{Key variables in land use - travel behaviour research}

5 Numerous studies exist that measure the effects of the land use patterns on travel behaviour. Literature reviews (e.g., Ewing and Cervero, 2001; van Wee, 2002) distinguish various land use characteristics, ranging from density and diversity measures to neighbourhood type and urban design features. Results are generally controlled for socio-economic differences, and a limited number of studies also take individual perceptions, attitudes and preferences into account. Consequently, key variables in these empirical studies refer to three components: (i) a spatial component, (ii) a socio-economic component and (iii) a personality component. In the next subsections, we summarize some main findings of empirical studies on land use - travel behaviour.

\section{Spatial component}

6 Land use characteristics can be measured at several scales, ranging from the local neighbourhood to the metropolitan area. Usually, four important components are distinguished: density, diversity and design (Cervero and Kockelman, 1997) and accessibility (Geurs and van Wee, 2004). 
7 The effects of density on travel demand have long been acknowledged (e.g., Levinson and Wynn, 1963) and remain well-studied and understood. Higher densities are associated with more public transport use, more walking and cycling, and less car use. After all, public transport is organized more efficiently (more routes, higher frequency of services) in high-density areas and car users may face more congestion. Furthermore, travel distance and time is negatively associated with density (Cervero and Kockelman, 1997; Kitamura et al., 1997; Stead, 2001; Schwanen et al., 2004).

8 Several measures have been developed to estimate diversity: among others, a jobs/ housing ratio (Ewing et al., 1994), an entropy index to quantify the degree of balance across various land use types (Frank and Pivo, 1994; Kockelman, 1997) or a dissimilarity index to indicate the degree to which different land uses lie within one another's surrounding (Kockelman, 1997). The effects of more diversity on travel behaviour are comparable to the effects of higher densities.

9 The factor design can be characterized by a general classification of neighbourhoods with a standard suburban neighbourhood and a neo-traditional neighbourhood as extremes (McNally and Kulkarni, 1997; Gorham, 2002). Standard suburban neighbourhoods are characterized by low densities, limited diversity, and a carorientated design. As a consequence, these neighbourhoods are associated with more trips and more car use. However, design can be characterized more specifically by site design, and dwelling and street characteristics. Studies indicate that neighbourhoods characterized by small block sizes, a complete sidewalk system, the absence of cul-desacs and limited residential parking encourage walking and cycling (Cervero and Kockelman, 1997; Hess et al., 1999; Stead, 2001). Meurs and Haaijer (2001) noted that, although characteristics of the dwelling, street, and neighbourhood may influence modal choice, this is only true for shopping and social or recreational purposes. Working trips are, for instance, less influenced by design characteristics.

10 Accessibility is a fourth important land use characteristic. Accessibility has become a frequently used concept, but its meaning always refers to the ability "to reach activities or locations by means of a (combination of) travel mode(s)" (Geurs and van Wee, 2004). Most studies agree on the effects of accessibility on travel behaviour. For example, based on a sample from the Sacramento County (USA), Gao et al. (2008) found that households living in residential locations with higher job accessibility are likely to own fewer cars. Kitamura et al. (1997) found for five neighbourhoods in San Francisco that better accessibility levels by public transport result in more trips by public transport. Several studies also point out that accessibility is negatively associated with travel times (e.g., Ewing et al., 1994; Shen, 2000; Susilo and Maat, 2007).

\section{Socio-economic component}

11 An important and very straightforward socio-economic variable that explains travel behaviour is car ownership: households owning a car will use it. However, car ownership in itself is influenced by other socio-economic variables, especially income. Car ownership is higher among high-income groups (Kockelman, 1997; McNally and Kulkanri, 1997; Dieleman et al., 2002; Schwanen et al., 2002, 2004). Car ownership, and consequently car use, is lower among older persons (aged above 65 years). Moreover, if older persons travel by car, they travel shorter distances. Note also that older persons not only travel because they want to participate in activities, the travelling itself has 
socializing opportunities. Ride-sharing for non-work trips is, therefore, found to increase by age (Stead, 2001; Schwanen et al., 2004).

Women travel more often by public transport, by bike or on foot, whereas car use is higher among men. Because women tend to rely more on slow transport modes, their travel is restricted to shorter distances (Stead, 2001; Schwanen et al., 2002, 2004). This gender difference is partly explained by the fact that women earn lower wages and work in different types of jobs than their male colleagues (Madden, 1981; Hanson and Pratt, 1988).

Educational level, employment status, and income are related, resulting in comparable findings. Higher educated persons obtain more specialized and higher paid jobs which are concentrated in high-density office parks. As a result, they are more involved in long-distance commuting and car use is higher (Kockelman, 1997; Stead, 2001; Schwanen et al., 2002; Krizek, 2003). However, the use of public transport, especially train use, is higher if these office parks are located nearby a train station.

Household size is positively associated with car ownership. Because of intra-household decisions related to the activities of several household members, it may be appropriate to own more cars. Households that own a car will use it more often. Furthermore, because these households are more car dependent, they travel longer distances as well (Kockelman, 1997). Comparable results are found with respect to the number of employed persons in the household (Cervero and Kockelman, 1997; Krizek, 2003) and the presence of children. However, travel distances and times are longer for singles and childless couples, because they do not have child care responsibilities (Stead, 2001; Dieleman et al., 2002; Schwanen et al., 2002). The influences of these household characteristics on the individual's daily travel behaviour are examples of contextual effects, as called in econometrics (Blume and Durlauf, 2005; Durlauf and Cohen-Cole, 2005).

\section{Socio-psychological component}

15 In the 1970s, various studies focused on perceptions and attitudes in travel behaviour (e.g., towards travel modes, Hartgen, 1974; Golob and Recker, 1977; Dobson et al., 1978). However, these studies did not include a spatial component. Recent travel behaviour studies rediscover the importance of perceptions and attitudes. Attitudes towards urban form (Handy, 1996) and towards travel (Bagley and Mokhtarian, 2002; van Wee et al., 2002) add explanatory power to models of travel behaviour that already include spatial and socio-economic variables. Moreover, perceptions and attitudes are considered as the result of lifestyles. The study of lifestyles in travel behaviour research is, therefore, becoming more important (Kitamura et al., 1997; Bagley and Mokhtarian, 2002).

\section{Interdependencies}

16 Interdependencies may exist between previously mentioned components. For example, most recently, there is a growing interest in the issue of residential self-selection (e.g., Bagley and Mokhtarian, 2002; Cao et al., 2006; Bhat and Guo, 2007; Pinjari et al., 2007). This issue refers to the potential problem that people might self-select themselves into different residential neighbourhoods. In other words, people's residential location 
decision might be based on their socio-economic characteristics (e.g., income) or sociopsychological characteristics (e.g., travel preferences). Consequently, the connection between land use and travel behaviour might be more a matter of residential location choice. Or in modelling terms: can land use characteristics be considered as exogenous variables in the model, or are these land use characteristics function of other variables? This refers to the problem of endogeneity, as called in econometrics (Blume and Durlauf, 2005; Durlauf and Cohen-Cole, 2005). After controlling for residential selfselection, Bagley and Mokhtarian (2002) and Cao et al. (2006) found little effect of land use on travel behaviour, whereas Bhat and Guo (2007) and Pinjari et al. (2007) found the opposite.

Comparable to previously mentioned interdependencies, several aspects of travel behaviour might be related to each other. Whereas most empirical studies focus on the effect of land use on a specific aspect of travel behaviour, it might also be useful to consider several aspects of travel behaviour simultaneously. For example, some studies indicated that car ownership mediates the relationship between land use and mode choice (e.g., Schimek, 1996; Simma and Axhausen, 2003; Chen et al., 2008; Van Acker and Witlox, 2008). Individuals and households owning a car will use it more often. Consequently, indirect effects of the land use pattern on car use will occur. For commuting trips in particular, the decision to commute by car might be based on the commuting distance. In most cases, workers always commute to the same workplace and, thus, commuting distance is unchangeable and might become a factor on which the mode choice is based. Longer commuting distances will favour the decision to commute by car (e.g., Cervero, 1996; Cervero and Kockelman, 1997). Contrary to commuting distance, mode choice is not based on commuting time. Commuting time is influenced by mode choice, and not the other way around. Aside from the disturbing influence of congestion, commuting time is related to the velocity of the chosen travel mode and commuting distance. The car is a faster travel mode than public transport, walking or biking, and will result in shorter commuting times. Being all else equal, shorter commuting times can also be the result of short commuting distances (Schwanen et al., 2002; Van Ommeren and Dargay, 2006; Susilo and Maat, 2007).

\section{Theorizing on land use - travel behaviour}

In the previous section, an overview of the commonly used variables in travel behaviour research was given. These variables relate to spatial, socio-economic and socio-psychological aspects. Although, the reviewed studies use a variety of models and approaches, none of these studies advance an overall theoretical framework that justifies and explains the revealed triad relationship. Clearly, such a theoretical justification cannot be found in one comprehensive theory. Nevertheless, concepts from several theories in transport geography and social psychology can contribute to the research debate. In what follows, we will only review theories that depart from a disaggregate perspective. In other words, theories with an aggregated approach, such as spatial interaction models, are not considered because they empirical do not provide insights into the mechanisms underlying people's travel behaviour (Hanson and Schwab, 1986). This paper aims at a better understanding of how people travel. 


\section{Travel behaviour as part of a decision hierarchy}

In transport geography, daily travel behaviour is considered as a part of a decision hierarchy. This hierarchy consists of short-term decisions on daily activities, mediumterm decisions on residential and workplace locations, and long-term decisions on lifestyle ((e.g., Ben-Akiva, 1973; Salomon, 1981; Salomon and Ben-Akiva, 1983). Our comprehensive conceptual model of daily travel behaviour also departs from this notion and, therefore, the decision hierarchy is at centre of Figure 1. In this section, we provide a theoretical justification of this decision hierarchy.

Figure 1. A comprehensive conceptual model for travel behaviour.

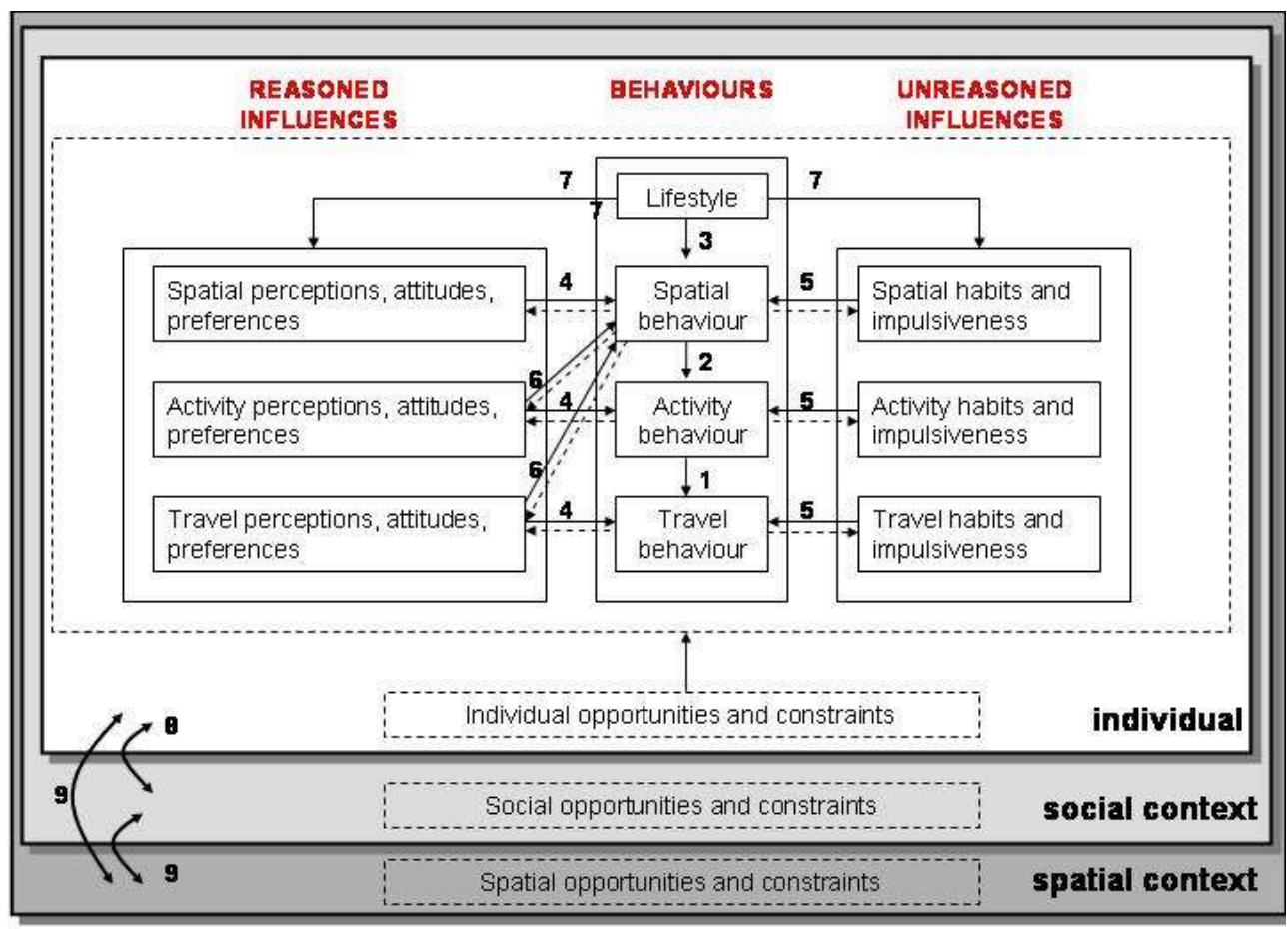

Travel behaviour and short term activity decisions

Nowadays, travel is generally considered as a derived demand. Although sometimes people might travel just "for fun" (e.g., Mokhtarian and Salomon, 2001; Mokhtarian et al., 2001), people mainly travel in order to access desired activities in other locations. After all, activities such as living, working, shopping and recreating are in most cases spatially separated and, thus, encourage the need to travel. Consequently, activity behaviour must be studied first in order to understand travel behaviour (arrow 1 in Figure 1) (Pas, 1980; Jones et al., 1990; Axhausen and Gärling, 1992; McNally, 2000). This idea has been further elaborated in the activity-based approach. Seminal theoretical contributions have been made by Hägerstrand (1970), Chapin (1974) and Cullen and Godson (1975). Hägerstrand (1970) suggested a spatiotemporal framework: geographers should not only analyze the spatial aspects of the individual's activity pattern, but also the temporal aspects of it. Therefore he introduced the concepts of space-time paths and space-time prism (STP). Whereas the path describes the observed movement throughout space and time of an individual, the prism indicates what portions of space 
are accessible for an individual at each moment in time (Lenntrop, 1976; Miller, 1991, Neutens et al., 2007). Such a path and prism are easy to construct for one person. However, it becomes more difficult when the activity pattern of several persons must be analyzed. Most studies in time geography, therefore, focus on constraints (i.e. capability constraints, coupling constraints, and authority constraints) that influence time-space paths and prisms. Whereas Hägerstrand (1970) explained the observed activity patterns within a spatiotemporal framework, Chapin (1974) described a motivational framework in which activity patterns result from the interaction between individual propensities and perceived opportunities to engage in activities. He argued that the individual's propensity to engage in an activity can be facilitated as well as constrained. Facilitating factors refer to individuals' motivations and ways of thinking that predispose individuals to participate in activities, whereas constraining factors do the opposite. Examples of constraining factors are role and personal characteristics such as household responsibilities, gender and age. As a result, Chapin (1974) suggested that different socio-economic groups adopt different activity patterns. This fact clearly justifies the incorporation of a socio-economic component in empirical studies on land use - travel behaviour. The theoretical frameworks of Hägerstrand (1970) and Chapin (1974) seem complementary: Hägerstrand focussed on spatial and temporal constraints, whereas Chapin emphasized the influence of opportunities and choices (Ettema and Timmermans, 1997). Cullen and Godson (1975) attempted to combine both frameworks. They characterized the spatial and temporal constraints identified by Hägerstrand by varying degrees of flexibility. Temporal constraints are less flexible than spatial constraints. Moreover, flexibility is closely related to activity type. For example, workrelated activities are less flexible than leisure activities, and routine-like activities tend to be fixed in space and time. Whereas most other activity-based studies analyze the revealed activity patterns, Cullen and Godson (1975) also tried to explain the underlying activity scheduling process. Particular activities, such as working activities, act as "pegs" around which other activities are arranged according to their flexibility. They also suggested that activities can be planned consciously or more routine-like (Ettema and Timmermans, 1997; Bhat and Koppelman, 1999; Lee and McNally, 2003). Since the 1970s, considerable progress has been made in activity-based travel research (for a recent review, see, e.g., Algers et al., 2005; Buliung and Kanarogloy, 2007). One important development is the focus on intra-household and social interactions. The individual is the primary unit of analysis in most activity-based travel studies, but attention recently shifted toward the complex interactions between individuals (e.g., household members, friends, colleagues) and how this influences activity and travel behaviour (e.g., Neutens et al., 2007b, 2008; Paez and Scott, 2007; Schwanen, 2007, 2008; Schwanen et al., 2007, Srinivisan and Bhat, 2008).

\section{Travel behaviour and medium term spatial decisions}

21 In their synthesized theory on travel behaviour, Fried et al. (1977) related travel behaviour directly to activity behaviour. However, it is possible that the distribution and location of activity opportunities do not match the individual's activity needs. In this case, the individual tries to reduce this imbalance by adaptations ranging from short-term travel and activity adjustments to longer term changes such as residential or workplace relocation. Such longer term changes only occur if short-term adjustments do not sufficiently reduce the imbalance between activity opportunities 
and needs. Cullen (1978) stressed that longer term changes are not frequently made, but are well-reasoned and determine the social and spatiotemporal context in which daily activity behaviour is performed. Consequently, longer term changes have a considerable influence on everyday activity and travel behaviour (arrow 2 in Figure 1). Since the 1970s, empirical research continued on the relationship between travel behaviour and these spatial medium-term decisions. Particularly, the influence of residential location choice attained attention. A number of studies (e.g., Levinson, 1997; Clark et al., 2003; Scheiner, 2006) point out that mode use, travel distances and activity spaces all change after a residential relocation. At the same time, residential relocations can occur because of dissatisfying routines of mode use, as well as distances and locations of daily activities. The complex interdependencies of travel and residential location choices challenge the question whether the characteristics of the residential neighbourhood themselves influence travel behaviour. Several recent studies (e.g., Schwanen and Mokhtarian, 2005a, b; Bhat and Guo, 2007; Cao et al., 2007a, b; Pinjari et al., 2007; Mokhtarian and Cao, 2008) argue that attitudes and preferences toward travel and residential neighbourhoods are the true determinants of travel patterns. Individuals and households self-select themselves into a residential neighbourhood that is consistent with their attitudes and preferences.

\section{Travel behaviour and long term lifestyle decisions}

The longest term decision is the choice of a lifestyle. Short-term activity decisions and medium-term spatial decisions are made by the individual to satisfy his or her lifestyle decision. This way, lifestyle also influences daily travel behaviour (arrow 3 in Figure 1). The impact of lifestyle on travel behaviour has certainly increased. Processes of increasing prosperity, increasing individualization and decreasing social control allowed people to lead a personal lifestyle (Ferge, 1972; Bootsma et al., 1993). Consequently, different lifestyle may exist within socio-economic homogenous groups.

Despite its frequent colloquial use, a distinct lifestyle theory is hard to find. Lifestyle is elaborated pragmatically, rather than theoretically (e.g., Sobel, 1983). Nevertheless, some theoretical contributions to the lifestyle concept are made by Weber (1972), Bourdieu (1984) and Ganzeboom (1988).

Weber (1972) criticized Marx's class theory, in which behaviour is determined by the economic position of the individual (i.e., the possession of means of production). Weber (1972) concluded that behaviour cannot be explained by social class exclusively. Therefore, he added the concept of status, which refers to a group of people that shares the same prestige and obtain a similar lifestyle. Lifestyle is considered as a pattern of observable and expressive behaviours. Consequently, people with the same status, and thus the same lifestyle, will tend to behave similarly.

Following Weber (1972), Bourdieu (1984) considered lifestyle as a pattern of behaviours indicating the social position of the individual. Each individual occupies a position in a two-dimensional social space which is defined by the amount and the composition of capital. The amount of capital ranges from no capital to much capital, the composition of capital ranges from economic capital to socio-cultural capital. Thus, capital not only refers to economic capital such as money and real estates, but to cultural capital (i.e., education, knowledge, skills) and social capital (i.e., relations, networks) as well. Within this two-dimensional space, traditionally used socio-economic variables define the "space of social position", whereas specific patterns of behaviour define the "space of 
lifestyles". Based on this, two hierarchies can be distinguished. One category reaches from the traditional lower status groups to the economic elites. Another category reaches from the same lower status groups to the cultural elites. Thus, various lifestyles only appear among social groups with high capital levels. The economic elites pursue material welfare and obtain rather traditional aesthetic and moral beliefs, whereas the cultural elites display their knowledge, for example on contemporary art.

Ganzeboom (1988) elaborates further on the work of Weber and Bourdieu (1984) as he assumes that people symbolize and clarify their social position through a pattern of behaviours. This behaviour is determined by their lifestyle. Based on their lifestyle, people have preferences on how to present themselves socially. These preferences are balanced against available opportunities and constraints, which results in the actual behaviour. In order to obtain a more precise definition, Ganzeboom (1988) discusses the origins and function of lifestyles. Lifestyle is related to the individual's socio-economic characteristics. However, this relationship is influenced by intermediate variables which refer to opportunities and constraints offered by time budget, income, cognitive skills (i.e., knowledge, skills) and status considerations (i.e., the influence of the social environment, the aim to obtain social appreciation). Time budget and income can be measured objectively, whereas cognitive skills and status considerations are rather subjective. These four intermediate variables are internal to the individual. An additional, but external, intermediate variable consists of institutions (i.e., rules, regulations). Lifestyles must not be considered as unambiguous types. Ganzeboom (1988) stresses the existence of a continuum between lifestyle types rather than the occurrence of unambiguous lifestyle types. This continuum is determined by three dimensions: (i) an economic dimension, (ii) a cultural dimension, and (iii) a stage in lifedimension. The first two dimensions are inspired by Bourdieu (1984). However, Ganzeboom (1988) considers economic and cultural capital as two separate dimensions instead of the extremes of one dimension. By including a third stage-in-life dimension, Ganzeboom is able to distinguish stable socio-economic background variables (e.g., gender) from changeable characteristics of stage in life (e.g., household composition, profession). He argues that some socio-economic variables have a dynamic nature and must, therefore, be treated differently. What resembles to be a free choice on a particular moment may restrict long-term choices. For example, educational choice may restrict further professional choices. As a result, an additional dimension, referring to stage in life, is added. This dimension operates in another way than the economic and cultural dimensions. No arguments can be put forward to consider one particular stage in life more important than another. In other words, no hierarchy can be found based on stage of life. Nevertheless, stage in life influences behaviour and preferences and, therefore, it should be included as a third dimension.

Weber (1972), Bourdieu (1984) and Ganzeboom (1988) agree on the communicative character of lifestyle: the individual elucidate his or her social position through specific patterns of behaviour. However, lifestyle includes more than observable patterns of behaviour. According to Ganzeboom (1988), lifestyle also refers to opinions and motivations (e.g., beliefs, interests and attitudes). This may confound our understanding of the lifestyle concept. For that reason, it is important to distinguish lifestyles from lifestyle expressions (Munters, 1992). In that case, lifestyles refer to the individual's opinions and motivations, or orientations. Lifestyles are mainly characterized by orientations towards family, work and leisure (Salomon and BenAkiva, 1983; Bootsma et al., 1993, Cooper et al., 2001; Hildebrand, 2003). Consequently, 
lifestyles are internal to the individual and, thus, are unobservable. A lifestyle, then, manifests itself in observable patterns of behaviour, or lifestyle expressions. In this way, observable patterns of behaviour (= lifestyle expressions) are explained by underlying opinions and orientations ( = lifestyles).

From the above, it should be clear how to measure lifestyles. Briefly summarized, lifestyle refers to the individual's orientations toward general themes such as family, work and leisure. Recently, several empirical studies try to include the individual's lifestyle within travel behaviour research. Most studies (e.g., Kitamura et al., 1997; Redmond, 2000; Bagley and Mokhtarian, 2002; Collantes and Mokhtarian, 2007) confirm that the lifestyle concept adds explanatory power to travel analyses. Scheiner (2006) and Scheiner and Holz-Rau (2007) refined these conclusions. They remarked that lifestyles do influence activity and travel behaviour. Nevertheless, the influence of objective socio-economic and demographic characteristics exceeds the influence of subjective lifestyles.

\section{Travel behaviour as the result of reasoned and unreasoned influences}

The previously described decision hierarchy might come across as a rigid framework that only observes behavioural patterns and not the underlying individual's motivations and intentions. Although general motivations and intentions are included in the decision hierarchy by the lifestyle concept, research indicates that individuals of socio-economic homogenous groups may still behave differently. This might be due to individual perceptions, attitudes and preferences toward spatial, activity and travel behaviour (van Wee, 2002; Mokhtarian and Cao, 2008). These specific subjective characteristics are different from the general one's that define lifestyle. Empirical activity-based travel studies do not generally incorporate these factors since most transport geographers find it difficult to put these factors into practice (Golledge and Stimson, 1997). Insights from theories in social psychology can help to overcome this problem. After all, social psychology focuses on how people think, feel and behave and how these thoughts, feelings and behaviours may be influenced by other people (Brehn et al., 2005). For this reason, combining insights from social psychology and previously described concepts from transport geography seems auspicious. Moreover, certain theories in social psychology argue that behaviour is not always well-reasoned through perceptions, attitudes and preferences. Behaviour has, thus, a reasoned component as well as an unreasoned component. These components underlie the decision hierarchy in our conceptual model of travel behaviour (see arrows 4 and 5 in Figure 1).

\section{Travel behaviour and reasoned influences}

The study of attitudes is a core topic in social psychology. An attitude refers to a positive, negative or mixed evaluative response to some stimuli (issues, objects or persons) which influences the individual's behaviour (Gärling et al., 1998 ; Brehn et al., 2005). Nevertheless, research indicates that the relationship between attitudes and behaviour is not perfect at all (e.g., LaPierre, 1934 ; Ajzen and Fishbein, 1977). Attitudes are not the only decisive factors of behaviour and, therefore, attitudes and behaviour must be treated within a broader context. This basic assumption is elaborated by Ajzen (1991) in the Theory of Planned Behaviour. Ajzen explains behaviour in terms of 
individual beliefs. These beliefs include behavioural beliefs, normative beliefs and control beliefs, which respectively influence attitudes, subjective norms and perceived behavioural control. Behavioural beliefs are beliefs about the probability of possible results of a behaviour. Those possible results are evaluated by the individual, determining the individual's attitude toward a behaviour. An individual's behaviour may depend on the approval of referent individuals (e.g. partner, friends, family, and boss). This is referred to as normative beliefs. Subjective norms about a behaviour are determined by those normative beliefs and the individual's motivation to go along with those referent individuals. Control beliefs are beliefs about the probability that particular factors will facilitate or constrain a behaviour. Perceived behavioural control is the result of those control beliefs taken into account the perceived power of each factor facilitating or constraining a behaviour. Attitudes, subjective norms and perceived behavioural control influence the intention to perform a specific behaviour.

31 The Theory of Planned Behaviour stresses the importance of individual beliefs. External factors, such as urban form, are not explicitly taken into account. However, particular urban form characteristics can be considered as factors facilitating or constraining behaviour (e.g., the presence of sidewalks will facilitate pedestrian trips). Consequently, control beliefs may include individual perceptions of the urban form. In other words, subjective perceptions of these factors are more important than objective measurement of it. Therefore, the theory distinguishes perceived behavioural control from actual behavioural control.

\section{Travel behaviour and unreasoned influences}

Nevertheless, the Theory of Planned Behaviour remains subject to criticism since it assumes rational decisions underlying behaviour. However, individuals are not constantly conscious of their behaviour (Simon, 1950; Pred, 1967). Triandis (1980) mentions the influence of habits. Moreover, he suggested a trade-off between attitudes and habits in the prediction of behaviour. If habits are strong, the attitude-behaviour relationship is weak, and vice versa (Traindis, 1977). Empirical studies such as Verplanken et al. $(1994,1998)$ confirmed this trade-off between habits and attitudes also exists in travel behaviour.

Ronis et al. (1989) formulated the theory of repeated behaviour. They remarked initial behaviour remains the result of relevant attitudes and beliefs. But once the behaviour is repeated, it becomes a habit and decision-making is no longer based on attitudes and behaviour. Repeated behaviour is, therefore, assumed to be mainly influenced by habits rather than by attitudes. Thus, three main categories of variables directly influence behaviour: (i) unreasoned influences, (ii) resources or enabling variables, and (iii) reasoned influences.

Recent advances in activity-based research account for unreasoned behaviour by studying activity scheduling and rescheduling processes (e.g., Doherty and Miller, 2000 ; Joh et al., 2004, 2005 ; Doherty, 2005 ; Lee and McNally, 2006 ; Zhou and Golledge, 2007). Activities are planned over varying time horizons. Activities such as working or shopping are weekly or daily recurrent activities. Planning such activities into a daily activity schedule is, thus, more a matter of routines or habits than of well-reasoned behaviour. These repeated activities (or habits) establish an initial skeleton schedule, in which well-reasoned decisions related to pre-planned activities as well as impulsive 
decisions related to events-of-the-day activities are fit in. As a result, activity schedules consist of a reasoned and an unreasoned component.

\section{The context of travel behaviour}

Previous sections describe travel behaviour from the perspective of the individual. Despite recent advances, external factors such as the social context and spatial context are generally ignored in studies on travel attitudes and habits. Nevertheless, accounting for the influence of the social and spatial context would help us clarifying the complex nature of travel behaviour. After all, the individual does not act within a "vacuous space". The individual is a member of a social network of family, friends and colleagues, lives within in a particular neighbourhood and travels to a specific destination. Consequently, the individual decision hierarchy and its underlying components must be considered within a social context and a spatial context (see arrows 7 and 8 in Figure 1). A theoretical explanation of the influence of the social context can be found in social cognitive theory. Ecological and environmental psychology provides a theoretical framework for the influence of the spatial context.

\section{Travel behaviour and the social context}

The social-cognitive theory postulates reciprocal relationships between the individual's characteristics, the individual's behaviour and the environment in which this behaviour is performed (Bandura, 1986). Within this theory, the environment mainly refers to the individual's social environment of which the household is the most important one. These reciprocal relationships may differ in strength and may occur on different points in time. Comparable to the theory of planned behaviour, a distinction is made between objective and subjective factors. The social-cognitive theory distinguishes environments and situations. Environments are objective quantifiable factors which are external to the individual, whereas situations refer to the individual's perception of this objective environment. For example, empirical travel studies indicate that the presence of young children in the household influences the parents' travel behaviour. This relationship can be measured by an objective variable such as "the number of children aged below 6 years" or by a subjective variable referring to the parents' attitude toward having and raising children. The concept of self-efficacy is considered as fundamental. Self-efficacy refers to the individual's self-confidence to overcome constraining factors and to perform a behaviour. This resembles the concept of perceived behavioural control defined by Ajzen (1991). Moreover, a learning behaviour appears, i.e. individuals learn that their behaviour has consequences and they expect the same results to occur again.

\section{Travel behaviour and the spatial context}

Environmental psychology resembles the social-cognitive theory. However, it underlines the role of the spatial context besides the social context. Environmental psychology questions the role of basic psychological intrapersonal processes, such as perception and cognition, in mediating the relationship between human behaviour and the environment. Intrapersonal processes such as perception indicate that behaviour is not only influenced by objective characteristics of the environment, but by the subjective evaluation of these characteristics as well (Stokols, 1977). For example, in his 
famous work The Image of the City, Lynch (1960) described how individuals perceive the built environment in terms of paths, edges, districts, nodes and landmarks. Behaviour is, thus, considered as the result of internal and subjective (personal) and external and objective (situational) characteristics. This was already noted by Lewin (1936) who stated:

$\mathrm{B}=\mathrm{f}(\mathrm{IP}, \mathrm{ED})$

where :

$\mathrm{B}=$ behaviour

IP = subjective intrapersonal processes (physiological and psychological)

$\mathrm{ED}$ = objective environmental dimensions (physical, social and cultural)

Moreover, environmental psychology acknowledges the multilevel data structure : a distinction is made between the intrapersonal level, interpersonal level and the community level. The concept of self-efficacy is important at the intrapersonal level, whereas the social context and its social norms refer to the interpersonal level. The community level includes the spatial context (Stokols, 1977 ; Handy, 2005).

\section{Individual, social and spatial opportunities and constraints}

The central box in our conceptual model refers to how the individual's reasoning determines travel behaviour. Habits as well as subjective characteristics, such as perceptions and attitudes, are important factors. Nevertheless, because of a lack of appropriate data most empirical studies on travel behaviour include objective characteristics instead of subjective factors. After all, objective characteristics of the individual, the social context and the spatial context might facilitate or constrain travel behaviour (for a review, see Ewing and Cervero, 2001 ; van Wee, 2002). For example, car use will be higher for individuals with a driving license, for households owning several cars and in suburban neighbourhoods. Therefore, the central box is also influenced by objective characteristics at each level of the conceptual model (see Figure 1).

\section{A comprehensive conceptual framework for travel behaviour}

Having discussed the key variables in travel behaviour research (section 2) and analyzed the different theoretical frameworks that exist (section 3), we now focus on putting forward a comprehensive conceptual model (see, Figure 1).

Travel behaviour consists of travel-related decisions, such as modal choice, travel distances and times, and combining trips into chains. Travel behaviour is considered as derived from short-term activity patterns (arrow 1 ), medium-term location-decisions (arrow 2) and long-term lifestyle decisions (arrows 3). Moreover, travel behaviour is the result of an assessment between preferences and habits, or in other words an assessment of reasoned influences and unreasoned influences. Following Ronis et al. (1989), initial behaviour depends more on reasoned influences, whereas habits will influence repeated behaviour. The same applies to other types of behaviour, namely spatiotemporal behaviour and activity behaviour (arrows 4 and 5). Spatial behaviour refers to all kinds of location-decisions (e.g., residential location, job location). Locationdecisions are not only influenced by spatial preferences, but also by activity and travel 
preferences (arrows 6) which refers to the self-selection mechanism. Activity behaviour includes the spatial and temporal activity pattern.

Spatiotemporal, activity and travel preferences are associated with attitudes and perceptions. Perceptions refer to the ways various aspects of the built environment, activities and travel are considered by an individual, whereas attitudes include an evaluation of these characteristics. Preferences are then formulated, based on these attitudes. This includes a ranking of different spatiotemporal, activity and travel opportunities. This line of reasoning is derived from theories in social psychology. Triandis (1980) considered habits as "situation-specific sequences that are or have become automatic, so that they occur without self-instruction" (Triandis, 1980, p. 204).

We argue that preferences and habits are influenced by the individual's lifestyle (arrows 7). Comparable to Ganzeboom (1988), we argue the individual's lifestyle influences preferences as well as habits. After all, it is possible that some lifestyle types are associated with more habitual behaviour than other lifestyle types. For example, an adventurous lifestyle permits less habitual behaviour and more impulsive behaviour than a cocooning lifestyle.

The model as a whole is influenced by (i) individual characteristics, (ii) characteristics of the social context, and (iii) characteristics of the spatial context. So far, empirical studies included these objective variables as control variables. For example, spatial opportunities are defined in terms of density, diversity and design. However, these objective variables are perceived and evaluated by individuals with specific lifestyles. It would be interesting to assess these objective variables with more subjective variables. For example, a neighbourhood is objectively evaluated as pedestrian friendly (e.g., low motorized traffic levels, availability of sidewalks). But an individual with a specific lifestyle might still consider this neighbourhood as unsafe (Handy, 1996).

The dotted arrows refer to feedback mechanisms : individuals can learn from previous experiences. Consequently, habits, perceptions, attitudes and preferences are not fixed in time.

\section{How to Account for Interdependencies?}

The above literature review and conceptual model reveal the complexity of travel behaviour. Numerous variables are influencing each other, resulting in indirect effects on travel behaviour. This kind of interdependency can be analyzed using Structural Equation Models (SEM). A second kind of interdependencies results from a nested data structure. Data are collected at several levels : socio-economic data is collected at the individual level and the household level, whereas spatial data is collected at the neighbourhood level and the metropolitan level. Moreover, individuals are nested within households, and households within neighbourhoods. This nested data structure is best analyzed using a multilevel analysis. Combining both methodologies results in a multilevel SEM approach.

\section{Multilevel structural equation models}

A structural equation model is a series of simultaneously estimated structural (i.e., regression) equations. It can distinguish direct, indirect and total effects. Because a 
variable can be an independent variable in one equation but a dependent variable in another equation, SEM makes a distinction between "endogenous" and "exogenous" variables. Exogenous variables are not influenced by any other variable, but only influence other variables. In a graphical representation of a model, no paths (symbolized by arrows) will point towards exogenous variables and paths will only depart from exogenous variables towards other variables. Endogenous variables are influenced by exogenous variables, either directly or indirectly (Kline, 2005 ; Byrne, 2001 ; Raykov and Marcoulides, 2000).

A SEM can be composed of up to three sets of simultaneous models : (i) a measurement model for the endogenous variables, (ii) a measurement model for the exogenous variables, and (iii) a structural model (Golob, 2003). This full model is referred to as a "SEM model with latent variables". Latent variables are constructs which cannot be observed directly. Thus, latent variables must be defined in terms of underlying variables which are believed to represent the latent variable. These underlying and observable variables are called "indicators" or "manifest variables". The measurement model, therefore, defines the relationship between a latent variable and its indicators. The structural model represents the relationships between exogenous and endogenous variables. This structural model is defined by the matrices :

$\mathrm{Y}=\mathbf{B} \mathrm{Y}+\Gamma \mathrm{X}+\zeta[1]$

with

$\mathrm{Y}=\mathrm{L} \times 1$ matrix with endogenous variables

$\mathrm{X}=\mathrm{K} \times 1$ matrix with exogenous variables

$\mathbf{B}=\mathrm{L} \times \mathrm{L}$ matrix with regression coefficients relating endogenous variables to other endogenous variables

$\Gamma=\mathrm{K} \times \mathrm{K}$ matrix with regression coefficients relating exogenous variables to endogenous variables

$\zeta=\mathrm{L} \times 1$ matrix with residues of the endogenous variables

The estimation of a SEM-model is usually based on matching the observed covariance matrix with the model-based covariance matrix.

Interdependencies may result from interactions between variables at a certain level, but also from interactions between variables at different, hierarchical levels. For example, individuals are nested within households, and households are nested within neighbourhoods. Suppose we only have data on individuals and households. Statistical methods assume independence over these $N$ observations. But travel behaviour of these individuals may be influenced by their household characteristics, such as car ownership. Therefore, independence is assumed only over the $c$ households in this twolevel SEM (Kline, 2005). Ignoring similarities among individuals within households can result in biased estimates of the model's parameters and goodness-of-fit indexes. The proportion of the total variation in the individual's travel behaviour due to the variation between the households is expressed by the interdependency index :

$$
\rho=\frac{\sigma_{B}^{2}}{\sigma_{B}^{2}+\sigma_{W}^{2}}
$$

with $\quad \sigma_{B}^{2}=$ variation between households

$\sigma_{W}^{2}=$ variation within households 

research. The few exceptions are Chung et al. (2004) and Kim et al. (2004), but these studies estimated two-level models referring to the individual and the household. Consequently, both studies did not account for the influence of the built environment. Due to recent advances in software development, it is however possible to include a third level which refers to the neighbourhood characteristics. Furthermore, both studies did not underline the importance of indirect effects. Chung et al. (1994) only described direct effects of individual and household characteristics on travel behaviour, whereas Kim et al. (2004) distinguished indirect effects, but they did not underline its meaning. resulting in indirect effects on travel behaviour. Within this framework, the estimation of a SEM is appropriate. Moreover, the effects of a nested data structure must be taken into account as well. Consequently, multilevel SEM is the appropriate modelling technique to put the conceptual model into practice.

Another reason why SEM is appropriate can be found in the conceptual model. The presented conceptual model strongly emphasizes the importance of lifestyle, perceptions, attitudes and preferences. However, these are latent variables which 
cannot be observed directly. Therefore, data on indicators of lifestyle, perceptions, attitudes and preferences will have to be collected. The latent variables or constructs can be determined by a factor analysis, but relationships between the constructs can be modelled in a SEM.

Because it is possible to model indirect effects, to account for a nested data structure and to estimate constructs in a SEM, the approach is considered useful to entangle the complexity of travel behaviour. Applications remain scarce. In future work, we plan to validate our conceptual travel behaviour analysis framework, using a multilevel SEM. The first attempts (Van Acker et al., 2007) look most promising.

\section{BIBLIOGRAPHY}

AJZEN I. (1991), "The theory of planned behaviour", Organizational Behavior and Human Decision Processes, 50, 2, pp. 179-211.

AJZEN I. \& FISHBEIN M. (1977), “Attitude-behavior relations : A theoretical analysis and review of empirical research”, Psychological Bulletin, 84, pp. 888-918.

ALGERS S., ELIASSON J. \& MATTSON L.G. (2005), "Is it time to use activity-based urban transport models ? A discussion of planning needs and modelling possibilities”, Annals of Regional Science, 39, pp. 767-789.

AXHAUSEN K.W. \& GARLING T. (1992), “Activity-based approaches to travel analysis : Conceptual frameworks, models and research problems”, Transport Reviews, 12, pp. 324-341.

BAGLEY M.N. \& MOKHTARIAN P.L. (2002), “The impact of residential neighborhood type on travel behavior : A structural equation modeling approach", Annals of Regional Science, 36, 2, pp. 279-297.

BANDURA A. (1986), Social Foundations of Thought and Action : A Social Cognitive Theory, New Jersey, Prentice-Hall.

BEN-AKIVA M. (1973), Structure of Passenger Travel Demand Models. PhD dissertation, Department of Civil Engineering, MIT, Cambrigde, MA.

BHAT C.R. \& GUO J.Y. (2007), “A comprehensive analysis of built environment characteristics on household residential choice and auto ownership levels", Transportation Research B, 41, 5, pp. 506-526.

BHAT C.R. \& KOPPELMAN F.S. (1999), “A retrospective and prospective survey of time-use research", Transportation, 26, pp. 119-139

BLUME L.E. \& DURLAUF S.N. (2005), Identifying Social Interactions : A Review, SSRI Working Paper (available from http://www.ssc.wisc.edu/econ/archive/publist2005.htm).

BOOTSMA H., CAMSTRA R., DE FEIJTER H. \& MOL A. (1993), “Leefstijl : een dynamische levensorientatie", Rooilijn, 26, pp. 332-337.

BOURDIEU P. (1984), La Distinction, London, Routledge.

BREHN S.S., KASSIN S.M. \& FEIN S. (2005), Social Psychology, Boston, Houghton Mifflin Company. 
BULIUNG R.N. \& KANAROGLOY P.S. (2007), “Activity-travel behaviour research : Conceptual issues, state of the art, and emerging perspectives on behavioural analysis and simulation modelling", Transportation Reviews, 27, pp. 151-187.

BYRNE B.M. (2001), Structural Equation Modeling with AMOS. Basic Concepts, Applications, and Programming, Mahwah, Lawrence Erlbaum Associates.

CAO S., HANDY S.L. \& MOKHTARIAN P.L. (2006), “The influences of the built environment and residential self-selection on pedestrian behavior : Evidence from Austin, TX”, Transportation, 33, 1, pp. 1-20.

CAO X., MOKHTARIAN P.L. \& HANDY S.L. (2007a), “Do changes in neighborhood characteristics lead to changes in travel behavior? A structural equations modeling approach", Transportation, 34 , pp. 535-556.

CAO X., MOKHTARIAN P.L. \& HANDY S.L. (2007b), “Cross-sectional and quasi-panel explorations of the connection between the built environment and auto ownership", Environment and Planning A, 39, pp. 830-847.

CERVERO R. (1996), "Mixed land-uses and commuting : Evidence from the American housing survey", Transportation Research A, 30, 5, pp. 361-377.

CERVERO R. \& KOCKELMAN K. (1997), “Travel demand and the 3D’s : Density, diversity and design", Transportation Research D, 2, 3, pp. 199-219.

CHAPIN F.S., Jr. (1974), Human Activity Patterns in the City: What do People do in Time and Space, Toronto, John Wiley.

CHEN C., GONG H.M. \& PAASWELL R. (2008), "Role of the built environment on mode choice decisions : additional evidence on the impact of density", Transportation, 35, pp. 285-299.

CHUNG J.-H., KIM S., LEE Y.-K. \& CHOI Y.-S. (2004), “Multilevel structural equation model for activity participation and travel behaviour. Data from the Puget Sound Transportation Panel", Transportation Research Record, 1898, pp. 52-60.

CLARK W.A.V., HUANG Y.Q. \& WITHERS S. (2003), "Does commuting distance matter ? Commuting tolerance and residential change”, Regional Science and Urban Economics, 33, pp. 199-221.

COLLANTES G.O. \& MOKHTARIAN P.L. (2007), "Subjective assessments of personal mobility : What makes the difference between a little and a lot ?", Transport Policy, 14, pp. 181-192.

COOPER J., RYLEY T. \& SMITH A. (2001), “Contemporary lifestyles and the implications for sustainable development policy : lessons from the UK's most car dependent city ; Belfast", Cities, 18, pp. 103-113.

CULLEN I.G. (1978), "The treatment of time in the explanation of spatial behaviour", in : CARLESTEIN T., PARKES D. \& THRIFT N. (Eds.) Human Activity and Time Geography, London, Edward Arnold, pp. 27-39.

CULLEN I.G. \& GODSON V. (1975), “Urban Networks : The Structure of Activity Patterns”, Progress in Planning, 4, pp. 1-96.

DIELEMAN F.M., DIJST M. \& BURGHOUWT G. (2002), “Urban form and travel behaviour : Microlevel household attributes and residential context”, Urban Studies, 39, 3, pp. 507-527.

DOBSON R., DUNBAR F., SMITH C.J., REIBSTEIN D.V. \& LOVELOCK C. (1978), “Structural models for the analysis of traveler attitude-behavior relationship", Transportation, 7, pp. 351-363. 
DOHERTY S.T. (2005), "How far in advance are activities planned ? Measurement challenges and analysis" Transportation Research Record, 1926, pp. 41-49.

DOHERTY S.T. \& MILLER E.J. (2000), “A computerized household activity scheduling survey”, Transportation, 27, pp. 5-23.

DURLAUF S.N. \& COHEN-COLE S.N. (2005), "Social interactions and macroeconomics", in : KAMPFLEONARD K. (Ed.) Encyclopedia of Social Measurement, vol. 3, pp. 517-522.

ETTEMA D. \& TIMMERMANS H. (1997), “Theories and models of activity patterns", in : ETTEMA D. \& TIMMERMANS H. (Eds.) Activity-Based Approaches to Travel Analysis, Oxford, Pergamon, pp. 1-36.

EWING R. \& CERVERO R. (2001), “Travel and the built environment : a synthesis”, Transportation Research Record, 1780, pp. 87-114.

EWING R., HALIYUR P. \& PAGE G.W. (1994), “Getting around a traditional city, a suburban planned unit development, and everything in between", Transportation Research Record, 1466, pp. 53-62.

FERGE S. (1972), "Social differentiation in leisure activity choices", in : SZALAI A. (Ed.) The Use of Time : Daily Activities of Urban and Suburban Population in Twelve Countries, Den Haag, Mouton, pp. 213-227.

FRANK L.D. \& PIVO G. (1994), "Impacts of mixed use and density on utilization of three modes of travel : Single-occupant vehicles, transit and walking", Transportation Research Record, 1466, pp. 44-52.

FRIED M., HAVENS J. \& THALL M. (1977), Travel behavior - A synthesized theory, Boston, Boston College.

GANZEBOOM H. (1988), Leefstijlen in Nederland : Een Verkennende Studie, Rijswijk, Sociaal Cultureel Planbureau.

GAO S., MOKHTARIAN P.L., JOHNSTON R.A., 2008, “Exploring the connections among job accessibility, employment, income, and auto ownership using structural equation modeling", Annals of Regional Science, 42, pp. 341-356.

GARLING T., GILLHOM R. \& GARLING A. (1998), "Reintroducing attitude theory in travel behaviour research. The validity of an interactive interview procedure to predict car use", Transportation, 25, pp. 129-146.

GEURS K.T. \& VAN WEE B. (2004), “Accessibility evaluation of land-use and transport strategies : review and research directions”, Journal of Transport Geography, 12, pp. 127-140.

GOLLEDGE R.G. \& STIMSON R.J. (1997), Spatial Behavior : A Geographic Perspective, New York, The Guildford Press.

GOLOB T.F. (2003), “Structural equation modeling for travel behavior research", Transportation Research B, 37, 1, pp. 1-25.

GOLOB T.F. \& RECKER W.W. (1977), “Mode choice prediction using attitudinal data : A procedure and some results", Transportation, 6, pp. 265-286.

GORHAM R. (2002), “Comparative neighborhood travel analysis : An approach to understanding the relationship between planning and travel behaviour", in : MAHMASSANI H.S. (ed.) In Perpetual Motion : Travel Behavior Research Opportunities and Application Challenges, Amsterdam, Pergamon, pp. 237-260. 
HÄGERSTRAND T. (1970), “What about people in regional science ?", Papers of the Regional Science Association, 24, pp. 7-21.

HANDY S.L. (1996), "Urban form and pedestrian choices : Study of Austin neighbourhoods", Transportation Research Record, 1552, pp. 135-144.

HANDY S.L. (2005), Critical Assessment of the Literature on the Relationships among Transportation, Land Use and Physical Activity, Washington, Transportation Research Board.

HANSON S. \& PRATT G. (1988), "Reconceptualizing the links between home and work in urban geography”, Economic Geography, 64, 4, pp. 299-321.

HANSON S. \& SCHWAB M. (1986), "Describing disaggregate flows : Individual and household activity patterns", in : HANSON S. (Ed.) The Geography of Urban Transportation, New York, The Guildford Press, pp. 166-187.

HARTGEN D.T. (1974), "Attitudinal and situational variables influencing urban mode choice : Some empirical findings", Transportation, 3, pp. 377-392.

HESS P.M., MOUDON A.V., SNYDER M.C. \& STANILOV K. (1999), "Site design and pedestrian travel", Transportation Research Record, 1674, pp. 9-19.

HILDEBRAND E.D. (2003), "Dimensions in elderly travel behaviour : A simplified activity-based model using lifestyle clusters”, Transportation, 30, pp. 285-306.

JOH C.H., ARENTZE T. \& TIMMERMANS H. (2004) ? “Activity-travel scheduling and rescheduling decision processes. Empirical estimation of Aurora model", Transportation Research Record, 1898, pp. 10-18.

JOH C.H., DOHTERTY T. \& POLAK J.W. (2005), “Analysis of factors affecting the frequency and type of activity schedule modification”, Transportation Research Record, 1926, pp. 19-25.

JONES P.M., KOPPELMAN F.S. \& ORFEUIL J.P. (1990), “Activity analysis : state of the art and future directions", in : JONES P. (Ed.) Developments in Dynamic and Activity-Based Approaches to Travel Analysis, Aldershot, Gower, pp. 34-55.

KIM H.J., KIM D.H. \& CHUNG J.-H. (2004), "Weekend activity and travel behavior in a developing country. Empirical study using multilevel structural equation models”, Transportation Research Record, 1894, pp. 99-108.

KITAMURA R., MOKHTARIAN P.L. \& LAIDET L. (1997), “A micro-analysis of land use and travel in five neighborhoods in the San Francisco Bay Area”, Transportation, 24, 2, pp. 125-158.

KLINE R.B. (2005), Principles and Practice of Structural Equation Modeling, New York, Guilford Press.

KOCKELMAN K.M. (1997), “Travel behavior as function of accessibility, land use mixing, and land use balance. Evidence from San Francisco Bay Area", Transportation Research Record, 1607, pp. 116-125.

KRIZEK K.J. (2003), "Residential relocation and changes in urban travel : does neighbourhoodscale urban form matter ?", Journal of the American Planning Association, 69, 3, pp. 265-281.

LAPIERRE R.T. (1934), “Attitudes vs. action”, Social Forces, 13, pp. 230-237.

LEE M. \& MCNALLY M.G. (2006), “An empirical investigation on the dynamic processes of activity scheduling and trip chaining”, Transportation, 33, pp. 553-565.

LENNTROP B. (1976), "Path in Space-Time Environments : A Time-Geographic Study of the Movement Possibilities of Individuals", Lund Studies in Geography, series B, 44. Lund, Lund University. 
LEVINSON D.M. (1997), "Jobs and housing tenure and the journey to work", Annals of Regional Science, 31, pp. 451-471.

LEVINSON H. \& WYNN F. (1963), "Effects of density on urban transportation requirements", Highway Research Record, 2, pp. 38-64.

LYNCH K. (1960), The Image of the City, Cambridge, MA, Technology Press.

MADDEN J.F. (1981), “Why women work closer to home”, Urban Studies, 18, pp. 181-194.

MCNALLY M.G. \& KULKARNI A. (1997), “Assessment of influence of land use-transportation system on travel behaviour", Transportation Research Record, 1607, pp. 105-115.

MEURS H. \& HAAIJER R. (2001), "Spatial structure and mobility”, Transportation Research D, 6, pp. 429-446.

MCNALLY M.G. (2000), “The activity-based approach”, in : HENSHER D.A. \& BUTTON K.J. (Eds.) Handbook of Transport Modeling, Oxford, Pergamon, pp. 53-69.

MILLER H.J. (1991), “Modeling accessibility using space-time prism concepts within Geographical Information Systems", International Journal of Geographical Information Systems, 5, 3, pp. 287-301.

MOKHTARIAN P.L. \& CAO X.Y. (2008), "Examining the impacts of residential self-selection on travel behaviour : A focus on methodologies", Transportation Research B, 42, pp. 204-228.

MOKHTARIAN P.L. \& SALOMON I. (2001), "How derived is the demand for travel ? Some conceptual and measurement considerations", Transportation Research A, 35, pp. 695-719.

MOKHTARIAN P.L, SALOMON I. \& REDMOND L.S. (2001), “Understanding the demand for travel : It's not purely "derived“", Innovation : The European Journal of Social Science Research, 14, pp. 355-380.

MUNTERS Q.J. (1992), “Bestaan leefstijlen (nog) wel ?”, Sociologische Gids, 39, pp. 179-185.

NEUTENS, T., WITLOX, F., VAN DE WEGHE, N. \& DE MAEYER, P. (2007a), "Space-time opportunities for multiple agents : A constraint-based approach", International Journal of Geographic Information Science, 21, pp. 1061-1076.

NEUTENS T., WITLOX F., VAN DE WEGHE N. \& DE MAEYER, PH. (2007b) Human interaction spaces under uncertainty, Transportation Research Record, 2021, pp. 28-35.

PAEZ A. \& SCOTT D.M. (2007), "Social influence on travel behavior : A simulation example of the decision to telecommute", Environment and Planning A, 39, pp. 647-665.

PAS E.I. (1980), Toward the understanding of urban travel behavior through the classification of daily urban travel/activity patterns, Evanston, Northwestern University.

PINJARI A.R., PENDYALA R.M., BHAT C.M. \& WADDELL P.A. (2007), "Modeling residential sorting effects to understand the impact of the built environment on commute mode choice", Transportation, 34, pp. 557-573.

PRED A. (1967), Behavior and Location : Foundations for a Geographic and Dynamic Location Theory. Part I, Lund, The Royal University of Lund.

REDMOND L. (2000), Identifying and analyzing travel-related attitudinal, personality and lifestyle clusters in the San Francisco Bay Area, Davis, University of California - Davis.

RAYKOV T. \& MARCOULIDES G.A. (2000), A First Course in Structural Equation Modeling, Mahwah, Lawrence Erlbaum Associates. 
RONIS D.L., YATES J.F. \& KIRSCHT J.P. (1989), “Attitudes, decisions, and habits as determinants of repeated behavior”, in : PRATKANIS A.R., BRECKLER S.J. \& GREENWALD A.G. (Eds.), Attitude Structure and Function, Hillsdale, Lawrence Erlbaum Associates, pp. 213-239.

SALOMON I. (1981), Life style as a factor in explaining travel behavior. PhD thesis, Massachusettes Institute of Technology.

SALOMON I. \& BEN-AKIVA M. (1983), "The use of the life-style concept in travel demand models", Environment and Planning A, 15, pp. 623-638.

SCHEINER J. (2007), "Mobility biographies : Elements of a biographical theory of travel demand", Erdkunde, 61, pp. 161-173.

SCHEINER J. \& HOLZ-RAU C. (2007), "Travel mode choice : affected by objective or subjective determinants ?", Transportation, 34, pp. 487-511.

SCHIMEK P. (1996), "Household motor vehicle ownership and use : How much does residential density matter ?", Transportation Research Record, 1552, pp. 120-125.

SCHWANEN T. (2002), "Urban form and commuting behaviour : a cross-European perspective", Tijdschrift voor Economische en Sociale Geografie, 93, 3, pp. 336-343.

SCHWANEN T. (2007), "Gender differences in chauffeuring children among dual-earner families", Professional Geographer, 59, pp. 447-462.

SCHWANEN T. (2008), "Struggling with time : Investigating coupling constraints", Transport reviews, 28, pp. 337-356.

SCHWANEN T., DIJST M. \& DIELEMAN F.M. (2002), “A microlevel analysis of residential context and travel time", Environment and Planning A, 34, pp. 1487-1507.

SCHWANEN T., DIELEMAN F.M. \& DIJST M. (2004), "The impact of metropolitan structure on commute behavior in the Netherlands : A multilevel approach", Growth and Change, 35, 3, pp. 304-333.

SCHWANEN T., ETTEMA D. \& TIMMERMANS H. (2007), "If you pick up the children, I'll do the groceries : spatial differences in between-partner interactions in out-of-home household activities", Environment and Planning A, 39, pp. 2754-2773.

SCHWANEN T. \& MOKHTARIAN P.L. (2005a), "What affects commute mode choice : neighborhood physical structure or preferences toward neighborhoods ?", Journal of Transport Geography, 13, pp. 83-99.

SCHWANEN T. \& MOKHTARIAN P.L. (2005b), "What if you live in the wrong neighborhood? The impact of residential neighborhood type dissonance on distance travelled", Transportation Research D, 10, pp. 127-151.

SHEN Q. (2000), "Spatial and social dimensions of commuting”, Journal of the American Planning Association, 66, 1, pp. 68-82.

SIMMA A. \& AXHAUSEN K.W. (2003), "Interactions between travel behaviour, accessibility and personal characteristics : The case of Upper Austria", European Journal on Transport Infrastructure and Research, 3, 2, pp. 179-197.

SIMON H. (1950), "Modern organization theories", Advanced Management, 15, pp. 2-4.

SOBEL M.E. (1983), Lifestyle and social structure; concepts, definitions, analysis, New York, Academic Press. 
SRINIVASAN S. \& BHAT C.R. (2008), “An exploratory analysis of joint-activity participation characteristics using the American time use survey", Transportation, 35, pp. 301-327.

STEAD D. (2001), "Relationships between land use, socioeconomic factors and travel patterns in Britain", Environment and Planning B, 28, 4, pp. 499-528.

STOKOLS D. (1977), “Origins and directions of environment-behavioral research”, in : STOKOLS D. (Ed.) Perspectives on Environment and Behavior. Theory, Research and Applications, New York, Plenum Press, pp. 5-36.

SUSILO Y.O., MAAT K. (2007), “The influence of built environment to the trends in commuting journeys in the Netherlands", Transportation, 34, 5, pp. 589-609.

TORN A.B. \& BOSKER R.J. (1999), Multilevel Analysis, London, Sage Publications.

TRIANDIS H. C. (1977), Interpersonal behavior, Monterey, CA, Brooks/Cole Publishing Company.

TRIANDIS H.C. (1980), "Values, attitudes and interpersonal behaviour", in : HOWE H.E. Jr., \& PAGE M.M. (Eds.), Nebraska Symposium on Motivation, Lincoln, University of Nebraska Press, pp. 195-259.

VAN ACKER, V., WITLOX, F. \& VAN WEE, B. (2007), "The effects of the land use system on travel behaviour : A structural equation modelling approach", Transportation Planning and Technology, 30, 4, pp. 331-354.

VAN ACKER V. \& WITLOX F. (2008), “Car ownership as a mediating variable in car travel behaviour research", Journal of Transport Geography (under revision).

VAN OMMEREN J. \& DARGAY J. (2006), "The optimal choice of commuting speed : Consequences for commuting time, distance and costs", Journal of Transport Economics and Policy, 40, 2 , pp. 279-296.

VAN WEE B. (2002), “Land use and transport : Research and policy challenges”, Journal of Transport Geography, 10, pp. 259-271.

VAN WEE B., HOLWERDA H. \& VAN BAREN R. (2002), "Preferences for modes, residential location and travel behaviour : The relevance for land use impacts on mobility", European Journal on Transport Infrastructure and Research, 2, 3/4, pp. 305-316.

VERPLANKEN B., AARTS H., VAN KNIPPENBERG A. \& VAN KNIPPENBERG C. (1994), “Attitude versus general habit - Antecedents of travel mode choice”, Journal of Applied Social Psychology, 24, pp. 285-300.

VERPLANKEN B., AARTS H., VAN KNIPPENBERG A. \& MOONEN A. (1998), "Habit versus planned behaviour : A field experiment”, British Journal of Social Psychology, 37, pp. 111-128.

WEBER M. (1972), Wirtschaft und Gesellschaft, Tübingen, Mohr.

ZHOU J. \& GOLLEDGE R. (2007), "Real-time tracking of activity scheduling/schedule execution within a unified data collection framework", Transportation Research A, 41, pp. 444-463.

\section{ABSTRACTS}

Many studies try to measure the effect of land use patterns on daily travel behaviour of individuals. Results are controlled for socio-economic differences, and sometimes sociopsychological differences, among respondents. However, these studies do not mention why after all a relationship should exist between travel behaviour and spatial, socio-economic and sociopsychological attributes. This query can be answered by combining theories in transport 
geography and social psychology. Doing so, this paper aims to develop a conceptual model for travel behaviour that brings together concepts such as "spatiotemporal behaviour", "activity behaviour", "lifestyle", "attitudes" and "habits". Within this conceptual model two kinds of interdependencies are highly important: (i) interdependencies between explanatory variables, causing indirect effects on travel behaviour, and (ii) interdependencies between different data levels causing a nested data-structure. Structural equation models (SEM) are generally used to estimate indirect effects, whereas multilevel analysis account for the nested data structure. The paper recommends combining both statistical techniques in order to better understand the complexity of human travel behaviour.

Verscheidene studies trachten de invloed van de ruimtegebruik op het dagelijkse verplaatsingsgedrag van individuen te bepalen. Gewoonlijk worden de resultaten gecontroleerd voor socio-economische verschillen, en soms socio-psychologische verschillen, tussen de respondenten. Echter, vaak geven deze studies niet aan waarom zo'n relatie bestaat tussen verplaatsingsgedrag en ruimtelijke, socio-economische en socio-psychologische kenmerken. Om dit vraagstuk te beantwoorden moet men theorieën uit de transportgeografie in relatie brengen met theorieën uit de sociale psychologie. Door de belangrijkste concepten uit beide theorieën te gebruiken, wordt een conceptueel model voor verplaatsingsgedrag voorgesteld. Dit conceptueel model brengt concepten zoals "ruimtelijk-temporeel gedrag", "activiteitengebaseerd gedrag", "leefstijl", "attitudes" en "gewoonten" in relatie tot elkaar. Twee soorten relaties zijn van groot belang binnen dit conceptueel model: (i) relaties tussen verklarende variabelen onderling waardoor indirecte effecten op het verplaatsingsgedrag ontstaan, en (ii) relaties tussen de verschillende dataniveaus waardoor een geneste datastructuur ontstaat. Structurele equatiemodellen (SEM) worden gewoonlijk gebruikt om indirecte effecten te schatten, terwijl multiniveau analyses de geneste datastructuur in rekening brengen. Dit artikel stelt voor om beide statistische technieken te combineren opdat een beter inzicht in de complexiteit van het verplaatsingsgedrag van personen te bekomen.

\section{INDEX}

Keywords: transport geography, social psychology, multilevel structural equation model Trefwoorden transportgeografie, sociale psychologie, multiniveau structureel equatiemodel

\section{AUTHORS}

\section{VERONIQUE VAN ACKER}

Vakgroep Geografie, Universiteit Gent, veronique.vanacker@ugent.be

FRANK WITLOX

Vakgroep Geografie, Universiteit Gent, frank.witlox@ugent.be 